\title{
A Study on Investigating Learning Styles and Skills Learning Motivations for Mechanical Department Students in Vocational High Schools
}

\author{
Yao-Chung Chiang, Chi-Hsiang Chen, Yu-Cheng Liao, and Chin-Wen Liao
}

\begin{abstract}
This study tended to investigate the learning styles and skill-learning motivation for students of mechanical department in vocational high school, to understand the difference between learning styles and skill-learning motivation for those students with different background variables, correlation and predictive power. It used the day division mechanical department students in public senior vocational high schools as the research population, and carried out the stratified proportional cluster sampling and questionnaire survey method to conduct data collection. It totally sent out 800 questionnaires, and recollected 776 , after eliminated invalid questionnaire, a total of 758 valid questionnaires, obtained with a valid return rate $94.75 \%$. Then, data analyzed by using package software with statistical methods.
\end{abstract}

Index Terms-Mechanical department in vocational high schools, learning styles, skill-learning motivation.

\section{INTRODUCTION}

\section{A. Research Background and Motivation}

\section{1) Research background}

Taiwan's senior high schools adopted the shunt education system that junior high school students can choose to enroll either regular senior high schools or senior vocational high schools after their graduation. The technological and vocational education used the clustering course system which totally divided into 15 career clusters. When junior high school students choose the technological and vocational education, in addition to those whom clearly follow their own career goal and interests to choose the respective courses, other students may receive suggestions from their friends and families or these relative information from media, so as to know the optimal occupational fields or subjects for future job market, and some of them would choose those courses with only the order of priority from previous basic competence tests, therefore, these factors may affect students' decision-making of choosing the learning fields that they are not interested, thus it may cause them to lack of learning motivation and lower school performance, as well as failed to

Manuscript received April 20, 2015; revised July 13, 2015.

Y.-T. Chiang, C.-H. Chen, and C.-W. Liao are with the Department of Industrial Education and Technology, National Changhua University of Education (NCUE), Taiwan (e-mail: cytsung@gmail.com, ccicjs2011@gmail.com, tcwliao@cc.ncue.edu.tw).

Y.-C. Liao is with the Department of Electrical Engineering, National Taiwan University of Science and Technology, Taiwan (e-mail: ms0605521@yahoo.com.tw). achieve the spirit of cultivating talents. Ministry of Education (2010) "Curriculum Outline and Equipment Standard in Vocational High Schools - Machinery Cluster" [1] proposed that vocational schools are to teach professional competence, cultivate professional ethics, incubate practical technical talents and establish their career development for students, and incubate them with having fundamental skills of machinery making, equipment operation and maintenance, as well as advance students to have good and safe working behaviors as their final educational goals. In addition, it also intends to cultivate them to have professional core competence, including the operation of machinery equipment, making and reading mechanical drawings, mechanical processing and making, operation and maintenance of electric mechanical system and diversified abilities to advance the higher education. Skills learning is emphasized the mechanical processing and making procedures according to the working drawing, and the operation of mechanical equipment to make the finished products, among which, the mechanical equipment means those processing machinery, including lathe, milling machine, planer, grinding machine etc.

\section{2) Research motivations}

1). To investigate the intensity of skill-learning motivation for students of mechanical department in vocational high school. The motivation of skill-learning will affect the behaviors and outcomes of skill-learning. [2]. 2). To investigate different learning styles that would affect their skill-learning motivation for those students of mechanical department in vocational high school. The outcomes of the skill-learning will be influenced by several factors, like curriculum designing, teaching situation, curriculum materials, teacher-student relationships, and learning patterns and skill-learning motivation of students [3]. Research indicated that the learning type of learners will have significant influences on learning effectiveness [4]. Moreover, researchers found that if the learners are more inclined to active type, thinking type, and theory-based type of learning patterns, they will get much better learning outcomes. In other words, different learning patterns will have different influence on learning outcomes [5].

\section{B. Research Purpose}

1) To understand the current status of learning styles and skill-learning motivation for students of mechanical department in vocational high school.

2) To investigate the difference in learning styles for students of mechanical department in vocational high school with different background variables. 
3) To investigate the difference in skill-learning motivation for students of mechanical department in vocational high school with different background variables.

4) To investigate the correlation between learning styles and skill-learning motivation for students of mechanical department in vocational high school.

5) To investigate the predictive power of learning styles to skill-learning motivation for students of mechanical department in vocational high school.

\section{RESEARCH DESIGN AND IMPLEMENTATION}

\section{A. Research Framework}

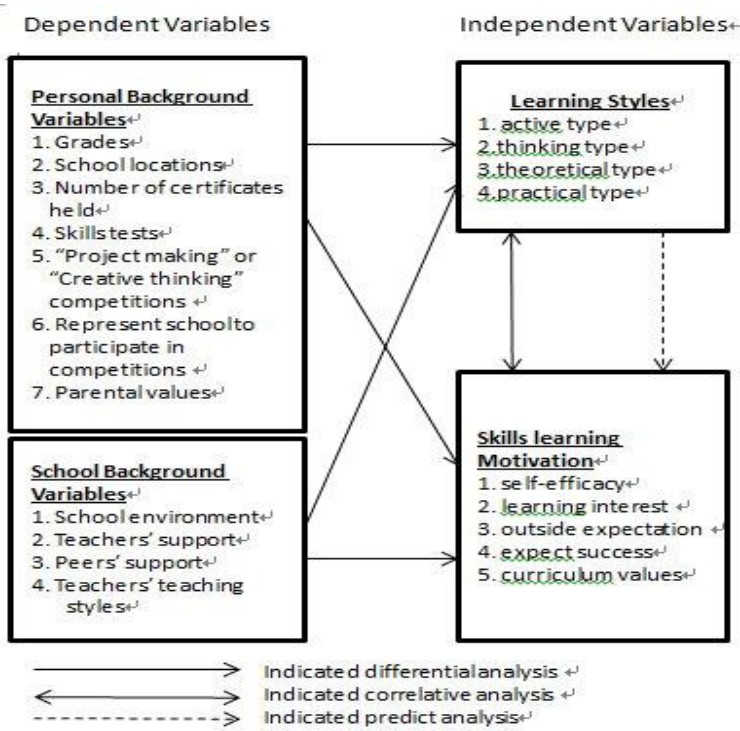

Fig. 1. Research framework diagram.

\section{B. Research Object}

It adopted first-year and second-year students of day division mechanical department in public vocational high schools in Taiwan areas from August 2012 to June 2013 as the research object, but excluding students of mechanical department in private vocational high schools, mechanical engineering curriculum, mechanical practical skills curriculum, co-op classes and advanced programs in public and private general high schools. It has divided into north, central and south areas, the research sample is obtained by using the stratified proportionate cluster sampling sampling.

\section{Research Method}

The self-edited "students of mechanical department in vocational high school learning styles and skill-learning motivation questionnaire" is used to be the research tool, and referred to these opinions from experts review to make further revisions in order to complete the pre-test questionnaire, and then carried out the pre-test and collected data for making follow-up analysis.

\section{Research Implementation}

\section{1) Pre-test phase}

It adopted schools as the sampling unit and used stratified proportional cluster sampling to choose 300 students as the object, and carried out the survey during the period from February to March 2014, it totally sent out 300 copies of questionnaire, and collected 280 copies, after eliminated 20 invalid ones, it obtained 260 valid copies of questionnaire with a valid return rate of $86.67 \%$.

TABLE I: PRE-TEST QUESTIONNAIRE OBJECT STRATIFIED SAMPLING TABLE

\begin{tabular}{|c|c|c|c|c|}
\hline Area & $\begin{array}{l}\text { Number of } \\
\text { Schools in } \\
\text { Each Area }\end{array}$ & $\begin{array}{l}\text { Percentage } \\
(\%)\end{array}$ & $\begin{array}{l}\text { Number of } \\
\text { Sampled Schools }\end{array}$ & $\begin{array}{l}\text { Pre-test } \\
\text { Sample } \\
\text { Number } \\
\text { (person) }\end{array}$ \\
\hline North & 13 & 27 & 1 & 60 \\
\hline Central & 18 & 38 & 2 & 120 \\
\hline South & 17 & 35 & 2 & 120 \\
\hline Total & 48 & 100 & 5 & 300 \\
\hline
\end{tabular}

TABLE П: PRE-TEST QUESTIONNAIRE SAMPLED SCHOOLS NAME LIST

\begin{tabular}{|c|c|c|}
\hline Area & Sampled Schools & \\
\hline North & $\begin{array}{l}\text { Pre-New Taipei } \\
\text { Municipal } \\
\text { San-Chung } \\
\text { Commercial and } \\
\text { Industrial Vocational } \\
\text { High School }\end{array}$ & \\
\hline Central & $\begin{array}{l}\text { National Pei-Kang } \\
\text { Agricultural \& } \\
\text { Industrial Vocational } \\
\text { High School }\end{array}$ & $\begin{array}{l}\text { National Dongshih Industrial High } \\
\text { School }\end{array}$ \\
\hline South & $\begin{array}{ll}\text { Kaohsiung } & \\
\text { Municipal } & \\
\text { Chung-Cheng } & \\
\text { Industrial } & \text { High } \\
\text { School } & \\
\end{array}$ & $\begin{array}{l}\text { National Kangshan Agricultural \& } \\
\text { Industrial Vocational Senior High } \\
\text { School }\end{array}$ \\
\hline
\end{tabular}

TABLE III: PRE-TEST QUESTIONNAIRE OBJECT STATISTICAL TABLE

\begin{tabular}{|c|c|c|c|c|c|c|}
\hline \multirow[b]{2}{*}{ Area } & \multirow[b]{2}{*}{ Sampled Schools } & \multicolumn{2}{|c|}{ Sampled Classes } & \multicolumn{2}{|c|}{ Sampled Students } & \multirow[b]{2}{*}{$\begin{array}{l}\text { Pre-test } \\
\text { Sample Size }\end{array}$} \\
\hline & & $\begin{array}{l}\text { First } \\
\text { Year }\end{array}$ & $\begin{array}{l}\text { Second } \\
\text { Year }\end{array}$ & $\begin{array}{l}\text { First } \\
\text { Year }\end{array}$ & $\begin{array}{l}\text { Second } \\
\text { Year }\end{array}$ & \\
\hline North & $\begin{array}{l}\text { Pre-New Taipei Municipal San-Chung Commercial and Industrial Vocational } \\
\text { High School }\end{array}$ & 1 & 1 & 30 & 30 & 60 \\
\hline \multicolumn{2}{|c|}{ North subtotal } & 1 & 1 & 30 & 30 & 60 \\
\hline \multirow{2}{*}{ Central } & National Pei-Kang Agricultural \& Industrial Vocational High School & 1 & 1 & 30 & 30 & 60 \\
\hline & National Dongshih Industrial High School & 1 & 1 & 30 & 30 & 60 \\
\hline \multicolumn{2}{|c|}{ Central subtotal } & 2 & 2 & 60 & 60 & 120 \\
\hline \multirow{2}{*}{ South } & Kaohsiung Municipal Chung-Cheng Industrial High School & 1 & 1 & 30 & 30 & 60 \\
\hline & National Kangshan Agricultural \& Industrial Vocational Senior High School & 1 & 1 & 30 & 30 & 60 \\
\hline \multicolumn{2}{|c|}{ South subtotal } & 2 & 2 & 60 & 60 & 120 \\
\hline
\end{tabular}




\section{2) Official questionnaire implementation phase}

TABLE IV: OFFICIAL QUESTIONNAIRE OBJECT STATISTICAL TABLE

\begin{tabular}{|c|c|c|c|c|c|c|}
\hline \multirow[b]{2}{*}{ Area } & \multirow[b]{2}{*}{ Sampled Schools } & \multicolumn{2}{|c|}{ Sampled Classes } & \multicolumn{2}{|c|}{ Sampled Students } & \multirow[b]{2}{*}{$\begin{array}{l}\text { Total } \\
\text { (person) }\end{array}$} \\
\hline & & $\begin{array}{l}\text { First } \\
\text { Year }\end{array}$ & $\begin{array}{l}\text { Second } \\
\text { Year }\end{array}$ & $\begin{array}{l}\text { First } \\
\text { Year }\end{array}$ & Second-Year & \\
\hline North & Taipei Municipal Xiufeng Senior High School & 2 & 2 & 80 & 80 & 160 \\
\hline \multicolumn{2}{|c|}{ Subtotal in north area } & 2 & 2 & 80 & 80 & 160 \\
\hline \multirow{2}{*}{ Central } & $\begin{array}{l}\text { The Affiliated Industrial Vocational High School of National Changhua } \\
\text { University of Education }\end{array}$ & 2 & 2 & 80 & 80 & 160 \\
\hline & National Hsin Chu Senior Industrial Vocational School & 2 & 2 & 80 & 80 & 160 \\
\hline \multicolumn{2}{|c|}{ Subtotal in central area } & 4 & 4 & 160 & 160 & 320 \\
\hline \multirow{2}{*}{ South } & Kaohsiung Municipal Kaohsiung Industrial High school & 2 & 2 & 80 & 80 & 160 \\
\hline & National Cishan Agricultural \& Industrial Vocational Senior High School & 2 & 2 & 80 & 80 & 160 \\
\hline \multicolumn{2}{|c|}{ Subtotal in south area } & 4 & 4 & 160 & 160 & 320 \\
\hline \multicolumn{2}{|l|}{ Total } & 10 & 10 & 400 & 400 & 800 \\
\hline
\end{tabular}

\section{RESEARCH CONTROL AND LIMITATION}

\section{A. Research Scope}

It adopted day division of mechanical department in public vocational high schools from 22 cities and counties in Taiwan areas as the research scope and divided into three areas.

\section{B. Research Limitation}

Research Object: it adopted day division mechanical department first-year and second-year students in public senior vocational high schools from 22 cities and counties in Taiwan areas as the population of this study. However, it still needs to investigate those objects that can be inferred outside the research scope.

Research Method: it used the questionnaire survey of quantitative research to carry out data collection and summarization, after verified the questionnaire survey experience, all of them are conformed to the tests of reliability and validity, bur researchers couldn't control the current mental factors for testees when they're filling questionnaire, and the correctness of their answers which resulted in some differences between collected data and actual status.

\section{DATA ANALYSIS AND DISCUSSION}

By focusing on research purposes and hypotheses, it analyzed and investigated the collected data according to the "students of mechanical department in vocational high school learning styles and skill-learning motivation survey questionnaire".

\section{A. Basic Data Analysis of Research Sample}

TABLE V: PERSONAL BACKGROUND VARIABLES ANALYSIS FOR MECHANICAL DEPARTMENT STUDENTS IN VOCATIONAL High SCHOOLS

\begin{tabular}{|c|c|c|c|c|}
\hline Variables & Category & Population & Percentage $\%$ & $\begin{array}{l}\text { Accumulative } \\
\text { Percentage } \%\end{array}$ \\
\hline \multirow{3}{*}{ Grade } & First-year & 388 & 51.2 & 51.2 \\
\hline & Second-year & 370 & 48.8 & 100.0 \\
\hline & Total & 758 & 100.0 & \\
\hline \multirow{4}{*}{ School Location } & North & 160 & 21.1 & 21.1 \\
\hline & Central & 289 & 38.1 & 59.2 \\
\hline & South & 309 & 40.8 & 100.0 \\
\hline & Total & 758 & 100.0 & \\
\hline \multirow{4}{*}{ Number of Certificates Held } & 0 & 463 & 61.1 & 61.1 \\
\hline & 1 & 268 & 35.4 & 96.4 \\
\hline & more than 2 (including) & 27 & 3.6 & 100.0 \\
\hline & Total & 758 & 100.0 & \\
\hline \multirow{3}{*}{ Certified Technician Tests } & applied & 658 & 86.8 & 86.8 \\
\hline & not applied & 100 & 13.2 & 100.0 \\
\hline & Total & 758 & 100.0 & \\
\hline \multirow{4}{*}{$\begin{array}{l}\text { Competitions of "project making" or "creative } \\
\text { thinking" }\end{array}$} & not in competitions & 675 & 89.1 & 89.1 \\
\hline & in competitions without won prizes & 56 & 7.4 & 96.4 \\
\hline & in competitions with won prizes & 27 & 3.6 & 100.0 \\
\hline & Total & 758 & 100.0 & \\
\hline \multirow{4}{*}{$\begin{array}{l}\text { Represent school to participate in competitions } \\
\text { (science fairs, skills competitions, creative invention } \\
\text { shows) }\end{array}$} & not in competitions & 668 & 88.1 & 88.1 \\
\hline & in competitions without won prizes & 52 & 6.9 & 95.0 \\
\hline & in competitions with won prizes & 38 & 5.0 & 100.0 \\
\hline & Total & 758 & 100.0 & \\
\hline \multirow{3}{*}{ Parental values } & would encourage & 706 & 93.1 & 93.1 \\
\hline & wouldn't encourage & 52 & 6.9 & 100.0 \\
\hline & Total & 758 & 100.0 & \\
\hline
\end{tabular}


1) Students' personal background variables include 7 items, such as grades, school location, number of certificates held, certified technician tests, competitions of "project making" or "creative thinking", representation of school to competitions, and parental values. The analytic results are organized as in Table V.

2) Students' school background variables are school environment, teachers' support, peers' support and teachers' teaching styles, and the analytic results are organized as in Table VI.

TABLE VI: SCHOOL BACKGROUND VARIABLES ANALYSIS FOR MECHANICAL DEPARTMENT STUDENTS IN VOCATIONAL HIGH SCHOOLS

\begin{tabular}{|c|c|c|c|c|}
\hline Variables & Category & Population & Percentage \% & $\begin{array}{l}\text { Accumulative } \\
\text { Percentage } \%\end{array}$ \\
\hline \multirow{3}{*}{ School Environment } & with & 724 & 95.5 & 95.5 \\
\hline & without & 34 & 4.5 & 100.0 \\
\hline & Total & 758 & 100.0 & \\
\hline \multirow{3}{*}{ Teachers' support } & would encourage & 725 & 95.6 & 95.6 \\
\hline & wouldn't encourage & 33 & 4.4 & 100.0 \\
\hline & Total & 758 & 100.0 & \\
\hline \multirow{3}{*}{ Peers' support } & would encourage & 578 & 76.3 & 76.3 \\
\hline & wouldn't encourage & 180 & 23.7 & 100.0 \\
\hline & Total & 758 & 100.0 & \\
\hline \multirow{4}{*}{ Teachers' teaching styles } & Autocratic style & 128 & 16.9 & 16.9 \\
\hline & Democratic style & 580 & 76.5 & 93.4 \\
\hline & Laissez-faire style & 50 & 6.6 & 100.0 \\
\hline & Total & 758 & 100.0 & \\
\hline
\end{tabular}

B. Analysis of Current Learning Styles and Skill-Learning Motivation for Students of Mechanical Department in Vocational High School

1) The analytic results of each aspect for learning styles in questionnaire for students of mechanical department in vocational high school discovered that the order sequence of aspects are "practical type", "thinking type", "active type" and "theoretical type", and means of each aspect are 4.19, 3.96, 3.62 and 3.23, respectively.

2) The analytic results of each aspect for skill-learning motivation in questionnaire for students of mechanical department in vocational high school discovered that the order sequence of aspects are "outside sector expectation", "expect success", "curriculum values", "learning interest", "self-efficacy", and means of each aspect are 4.29, 4.18, 4.01, 3.93, and 3.78, respectively.

C. Analysis of Difference in Learning Styles for Students of Mechanical Department in Vocational High School

1) Different grade students of mechanical department in vocational high school learning styles have not yet reached a significant difference $(t=1.383, p>.05)$ for overall aspect. It indicated that there's no difference.

2) Students of mechanical department in vocational high school in different locations whose learning styles have not yet reached a significant difference $(F=1.85, p>.05)$ for overall aspect. It indicated that there's no difference.

3) Different number of certificates held by students of mechanical department in vocational high school, their learning styles would be reached a significant difference $(t=-2.882, p<.01)$ for overall aspect, and it indicated that existed a difference. Mechanical department students with holding more than one (including) certificate(s) whose overall means of learning styles would be higher than mechanical department students without holding any certificate.

4) Different certified technician tests took by students of mechanical department in vocational high school, their learning styles would be reached a significant difference $(t=2.264, p<.05)$ for overall aspect, and it indicated that mechanical department students in vocational high schools who have experiences of applying Level $\mathrm{C}$ Certified Technician Tests, whose overall means of learning styles would be higher than those whom never applied.

5) "Project making" or "creative thinking" competitions took by mechanical department students in vocational high school, whose learning styles have reached a significant difference $(t=-3.847, p<.001)$ for overall aspect, and it indicated that a difference existed. Mechanical department students have participated in those competitions whose overall means of learning styles are higher than students who never participated in competitions.

6) Students of mechanical department in vocational high school represented schools to participate in such competitions whose learning styles have reached a significant difference $(F=9.68, p<.001)$ for overall aspect. It indicated that a difference existed. After carried out Scheffé Post-Hoc Comparison, the results discovered that mechanical department students $\ulcorner$ in competitions with won prizes $\lrcorner$ whose learning styles would be higher than students "not in competitions" for overall aspect.

7) Mechanical department students in vocational high school with different parental values whose learning styles have reached a significant difference $(t=5.513$, 
$p<.001)$ for overall aspect. It indicated that mechanical department students in vocational high school held a number of certificates, whose parents would encourage them to apply for certified technician tests that their learning styles would be higher than students whose parents didn't encourage them to take certified technician tests for all aspect.

8) Mechanical department students in vocational high school with school environment whose learning styles have reached a significant difference $(t=3.995, p<.001)$ for overall aspect. It indicated that mechanical department students in vocational high school whose schools have provided useful environment that overall means of their learning styles would be higher than students in schools without providing environment for better skills learning.

9) Students of mechanical department in vocational high school with different teachers' support whose learning styles have reached a significant difference $(t=3.474$, $p<.01)$ for overall aspect. It indicated that mechanical department students' teachers would encourage students to participate in "arts (skills) competitions" or "certified technician tests" whose learning styles would be higher than students with teachers wouldn't encourage students participate in " arts (skills) competitions".

10) Students with different Peers' support of mechanical department in vocational high school learning styles would be reached a significant difference $(t=7.127$, $p<.001)$ for overall aspects. It indicated that students with mutual encouragement among peers of mechanical department in vocational high school will have higher overall means of learning styles than students without mutual encouragement among peers.

11) Mechanical department students in vocational high school with different teachers' teaching styles whose learning styles have reached a significant difference $(F=8.08, p<.001)$ for overall aspect. It indicated that a difference existed. After carried out Scheffé Post-Hoc Comparison, it discovered that mechanical department students' awareness of teachers' teaching styles in practice course is belonged to "democratic style", which is higher than students with "laissez-faire style" teachers for overall aspect.

\section{Analysis for Students' Skill-Learning Motivation with} Different Background Variables

1) Different grade students of mechanical department in vocational high school whose skill-learning motivation have reached significant difference $(t=3.641, p<.001)$ for overall aspect. It indicated that a difference existed, and also meant that first-year mechanical department students whose means of skill-learning motivation is higher than second-year mechanical department students for overall aspect.

2) Mechanical department students in different vocational high school locations whose skill-learning motivation have to yet reached a significant difference $(F=1.109$, $p>.05)$ for overall aspect. It meant that no difference existed.

3) Different number of certificates held by mechanical department students in vocational high school whose skill-learning motivation have reached a significant difference $(t=-2.057, \quad p<.05)$ for overall aspect, it indicated a difference existed. Students are holding more than one (including) certificate whose skill-learning motivation would be higher than students without holding any certificate.

4) Different certified technician tests took by students of mechanical department in vocational high school whose skill-learning motivation have reached a significant difference $(t=4.323, p<.001)$ for overall aspect. It indicated that the overall means of mechanical department students in vocational high schools who applied Level C Certified Technician Tests would have a higher overall means of skill-learning motivation than students never applied Level C Certified Technician Tests.

5) Different competitions of "project making" or "creative thinking" took by mechanical department students in vocational high school whose skill-learning motivation have reached a significant difference $(t=-3.844, p<.001)$ for overall aspect, it meant that a difference existed. Mechanical department students who participated in such competitions whose overall means of skill-learning motivation would be higher than students never in competitions.

6) Mechanical department students in vocational high school represented their schools to participate in such competitions whose skill-learning motivation would be reached reached a significant difference $(F=7.304$, $p<.001)$ for overall aspect. It meant that a difference existed. After carried out Scheffé Post-Hoc Comparison, it discovered that mechanical department students in competitions with won prizes whose skill-learning motivation would be higher than students never in competitions for overall aspect.

7) Mechanical department students in vocational high school with different parental values whose skill-learning motivation have reached a significant difference $(t=6.589$, $p<.001)$ for all aspect. It indicated that parents would encourage them to participate in certified technician tests would have higher overall means of skill-learning motivation that those students whose wouldn't encourage them to participate in certified technician tests.

8) Mechanical department students in different vocational high school environment whose skill-learning motivation have reached a significant difference $(t=5.157, p<.001)$ for overall aspect. It meant that mechanical department students in vocational high school with providing better environment of skills learning would have higher overall means of skill-learning motivation than those students in schools without providing environment for better skills learning.

9) Mechanical department students in vocational high school with different teachers' support whose skill-learning motivation have reached a significant difference $(t=5.321, p<.001)$ for overall aspect. It indicated that mechanical department students' teachers who would encourage students to participate in "arts (skills) competitions" or "certified technician tests" 
whose overall means of skill-learning motivation is higher than students whose teachers wouldn't encourage them to participate in "arts (skills) competitions" or "certified technician tests".

10) Mechanical department students in vocational high school with different peers' support whose skill-learning motivation would have reached a significant difference $(t=6.740, p<.001)$ for overall aspect. It indicated that mechanical department students in vocational high school with mutual encouragement from peers whose overall means of skill-learning motivation would be higher than students without mutual encouragement among peers.

11) Different teachers' teaching styles Mechanical department students in vocational high school with different teachers' teaching styles whose skill-learning motivation have reached a significant difference $(F=9.007, p<.001)$ for overall aspect. It meant that a difference existed. After carried out Scheffé Post-Hoc Comparison, it discovered that mechanical department students whose teachers' teaching style is belonged to "democratic style"practical courses, their skill-learning motivation would be higher than those students' teachers' teaching styles belonged to "laissez-faire style" for overall aspect.

\section{E. Analysis of Correlation between Learning Styles and Skill-Learning Motivation for Mechanical Department Students}

1) Mechanical department students in vocational high school whose correlations between "learning interest" aspects and learning style aspects for skill-learning motivation are as follows: "active type" $(\gamma=.708, p<.001)$, "theoretical type" $(\gamma=.459, p<.001)$, "practical type" $(\gamma=.580, p<.001)$, "thinking type" $(\gamma=.432, p<.001)$, Except "active type" is belonged to a significant highly positive correlation, the rest of them showed a significant middle positive correlation .

2) Mechanical department students in vocational high school whose correlations between "curriculum values" aspects and learning style aspects for skill-learning motivation are as follows:"active type" $(\gamma=.533, p<.001)$, "theoretical type" $(\gamma=.495, p<.001)$, "practical type" $(\gamma=.631, p<.001)$, "thinking type" $(\gamma=.535, p<.001)$, Except "practical type" is belonged to a significant highly positive correlation, the rest of them showed a significant middle positive correlation .

3) Mechanical department students in vocational high school whose correlations between "outside sector expectation" aspects and learning style aspects for skill-learning motivation are as follows: "active type" $(\gamma=.511, p<.001)$, "theoretical type" $(\gamma=.331, p<.001)$, "practical type" $(\gamma=.597, p<.001)$, "thinking type" $(\gamma=.601, p<.001)$, Except "thinking type" is belonged to significant highly positive correlation, and "theoretical type" is belonged to significant low positive correlation, the rest of them showed a significant middle positive correlation .

4) Mechanical department students in vocational high school whose correlations between "self-efficacy" aspects and learning style aspects for skill-learning motivation are as follows: "active type" $(\gamma=.662, p<.001)$, "theoretical type" $(\gamma=.462, p<.001)$, "practical type" $(\gamma=.617, p<.001)$, "thinking type" $(\gamma=.449, p<.001)$, among which "active type" and "practical type" are belonged to a significant highly positive correlation, "theoretical type" and "thinking type" are belonged to a significant middle positive correlation.

5) Mechanical department students in vocational high school whose correlations between "expect success" aspects and learning style aspects for skill-learning motivation are as follows: "active type" $(\gamma=.495, p<.001)$, "theoretical type" $(\gamma=.331, p<.001)$, "practical type" $(\gamma=.551, p<.001)$, "thinking type" $(\gamma=.404, p<.001)$, Expect "theoretical type" is belonged to a significant low positive correlation, the rest of them is belonged to a significant middle positive correlation .

\section{F. Analysis of Predictive Power for Learning Styles and Skill-Learning Motivation of Mechanical Department Students in Vocational High School}

Analysis of difference of career exploration factors affecting career decision-making for students with different personal background variables: it adopted the diagnosis of Collinarity for Multiple Stepwise Regression Analysis. VIF values are between 1.593 and 1.850 , all lower than 10 , thus each aspect of learning styles would have no Collinarity to the skill-learning motivation. $F$ value of the overall regression model is $381.269, p=.000<.05$, with reaching a .05 significant level, which indicated that these 4 predictive variables, such as "practical type", "active type", "theoretical type" and "thinking type" and dependent variable of "skill-learning motivation" existed a significant correlation; that is, these 4 predictive variables abovementioned could certainly predict students' skill-learning motivation. In those predictive variables selected into the regression model, the aspect of "practical type" has the largest explanatory variance, which can solely predict skill-learning motivation to be $50.7 \%$ explanatory variance, next is the aspect of "active type", can solely predict skill-learning motivation to be $14.1 \%$ explanatory variance; in addition, both of their accumulative explanatory variances would be $64.8 \%$. Thus the overall predictive variables can predict dependent variables about $66.9 \%$ explanatory variance, as well as achieved a significant level $p<.001$, and it meant that learning styles have the predictive power to skill-learning motivation. $\beta$ values of predictive variables are positive values which indicated these 4 variables have a positive affecting power to skill-learning motivation, and they are, in order, "practical type" $(\beta=.394)$, "active type" $(\beta=.383)$, "theoretical type" $(\beta=.123)$ and "thinking type" $(\beta=.107)$.

\section{CONCLUSIONS AND SugGestions}

\section{A. Conclusions}

1) Learning styles of mechanical department students in vocational high school learning styles are mostly contained the "practical type", and least contained the "theoretical type": mechanical department students' 
"self-efficacy" can trigger weaker skill-learning motivation. The research results discovered that, in general, it cannot be able to effectively achieve the skills learning goal that teachers expected; in addition, students would not quite like to pay more time to repeatedly practice those skills, as well as lack of confidence to assist their classmates in solving any technical problem. Therefore, teachers of practical courses and curriculum should encourage students to repeatedly practice those skills in order to improve their competence and increase their confidence as well.

2) Along with "Support by parents, teachers and peers", "Good school environment", "Teachers with democratic teaching style", "Held skills certificates" and "Participated in relative competitions or certified technician tests" students of mechanical department in vocational high school would have higher learning styles and skill-learning motivation.

3) First-year mechanical department students in vocational high schools would have better skill-learning motivation. it discovered that "outside sector expectation" is the strongest factor of affecting first-year mechanical department students in vocational high schools for their skill-learning motivation, the next factor is "expect success", and the factor of "curriculum values" is the weakest factor; however, the affecting levels of these factors are all better than those second-year mechanical department students.

4) Mechanical department students in vocational high schools would show a highly positive correlation between their learning styles and skill-learning motivation: overall speaking, it showed a significant highly positive correlation between learning styles and skill-learning motivation for mechanical department students in vocational high school; therefore, it showed that characteristics of learning styles tend to be more significantly and clearly, then their affecting level to the skill-learning motivation will be larger as well.

5) The "practical type" learning styles would have high predictive power to the skill-learning motivation: types of learning styles would have predictive power to skill-learning motivation, and the intensity of predictive power would be in order "practical type", "active type", "theoretical type" and "thinking type", overall speaking, it can explain the level of skill-learning motivation to $67 \%$ explanatory variance, which meant that the characteristics of various learning styles tend to be more significantly and clearly, then their affecting level to the skill-learning motivation will be larger as well.

\section{B. Suggestions}

1) Suggestions to education authority are as follows:

- To supplement teaching-related equipment for mechanical department.

- To supplement mechanical professional competence books in library.

- To establish reward system.

- To improve the applying rate of certified technician tests and passing rate.

2) Suggestions to teachers of practice curriculum in mechanical department:

- To frequently encourage students to apply for certified technician tests and participate in various skills competitions.

- To advance students' skill-learning motivation.

- To cultivate students' competence to write the practice report.

3) Suggestions to parents of mechanical department students: parents' encouragement and support are their children's motive of skills learning, and properly express their expectation for children which showed, according to the Pygmalion Effect, their children's skills learning effectiveness would be improved as well.

4) Suggestions to follow-up researches are as follows

- In terms of research object: it can expand the research object to cover the first-year to the third-year, and both day and night divisions students in mechanical department and curriculum, so as to investigate the difference and correlation between learning styles and skill-learning motivation, thus it can make the research to be more completed and representative.

- As for the research methods: it suggested that these follow-up researchers can add qualitative researches and adopt interview method to understand testees' opinions more deeply in order to make up the insufficiency of quantitative research, and make the research to be more intact.

\section{REFERENCES}

[1] Ministry of Education. (2010). Curriculum outline and equipment standard in vocational high schools - Machinery cluster. [Online]. Available: http://course.tchcvs.tc.Edu.tw/

[2] L.-Y. Hsieh, "A study of correlation among learning motivation, behavior and effectiveness for students in practical curriculum in mechanical department of senior high (vocational) schools," Master thesis, National Changhua University of Education, Changhua, Taiwan, 2011.

[3] Y.-L. Lin, "The influence of personality traits and learning styles to learning performance (National Changhua University of Education)," Chaoyang University of Technology, Taichung, 2006.

[4] C.-A. Chen and W.-C. Wang, "A study of correlation between Learning styles and PE learning performance," Journal of Sports Health and Leisure, vol. 4, pp. 58-67, 2006.

[5] N. D. Fleming, Teaching and Learning Styles: VARK Strategies, Christchurch, New Zealand: N.D., 2001.

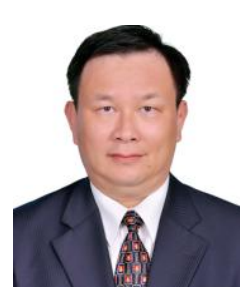

Yao-Tsung Chiang received his M.S. degree in agricultural machinery engineering from National Chung Hsing University in 2002, and currently is a doctoral student of the Department of Industrial Education and Technology at National Changhua University of Education (NCUE). Since August 2009, he had been the principal of National Chia-Yi Industrial Vocational High School until 2013, then transferred to be the principal of National Wufeng Agricultural and Industrial Vocational High School. Since August 1984, he has taught courses in agricultural machinery, mechanical drawing, introduction of computer science, frozen food machinery and introduction of machinery in National Yuanlin Agricultural and Industrial Vocational High School until 2009 .

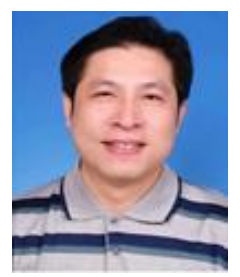

Chi-Hsiang Chen is a lecturer in the Department of Safety, Health and Environmental Engineering from Hung Kuang University, Taichung, Taiwan. He received his M.S. degree at the Department of Safety, Health and Environmental Engineering from Hung Kuang University, Taichung, Taiwan in 2008, and currently is a doctoral student at the Department of Industrial Education from National Changhua 
University, Changhua, Taiwan. He was a senior labor inspector in the Council of Labor Affair in Taiwan (from1988 to 2014). He has published papers in Journal of Loss Prevention in the Process Industries and others.

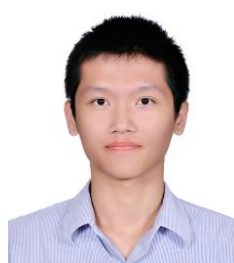

Yu-Cheng Liao graduated from Taichung Industrial Vocational High School, and now is studying in National Taiwan University of Science and Technology. He did a research with professor Liao in high school, and one of the research he did with his colleagues won the National Exhibition of Science and Technology competition. His research interests include technology and vocational education, teacher education, energy education of technology, and learning organization.

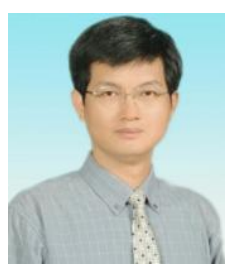

Chin-Wen Liao received both the M.S. and Ph.D. degrees in industrial education from National Taiwan Normal University, Taiwan, R.O.C. in 1994 and 2002, respectively. Since August 2011, he has been a professor in the Department of Industrial Education and Technology at National Changhua University of Education (NCUE) in Taiwan, R.O.C. He teaches courses in technology and vocational education, energy education, course and teaching, organizational learning. His research interests include technology and vocational education, teacher education, energy education of technology, and learning organization. 